\title{
Evolucijski algoritem za poravnavo sekvenc
}

\author{
Adel Bureković \\ Univerza v Mariboru \\ Fakulteta za elektrotehniko, \\ računalništvo in informatiko \\ Koroška cesta 46 \\ 2000 Maribor \\ burekovic.adel@gmail.com
}

\author{
Janez Brest \\ Univerza v Mariboru \\ Fakulteta za elektrotehniko, \\ računalništvo in informatiko \\ Koroška cesta 46 \\ 2000 Maribor \\ janez.brest@um.si
}

\author{
Borko Bošković \\ Univerza v Mariboru \\ Fakulteta za elektrotehniko, \\ računalništvo in informatiko \\ Koroška cesta 46 \\ 2000 Maribor \\ borko.boskovic@um.si
}

\section{POVZETEK}

$\mathrm{V}$ članku predstavimo reševanje problema poravnave bioloških sekvenc s pomočjo evolucijskega algoritma. Kandidate $\mathrm{v}$ populaciji smo evaluirali z metodo sume parov. Ker je problem lahko časovno zahteven, smo algoritem implementirali s pomočjo jezika $\mathrm{C}++$. Uspešnost algoritma smo testirali na DNK sekvencah različnih dolžin. Na skupini sekvenc povprečne dolžine 212 simbolov smo poravnali 111 stolpcev sekvenc. Pri sekvencah povprečne dolžine 1092 simbolov smo pa dosegli slabše rezultate z samo 43 poravnanimi stolpci.

\section{Kjučne besede}

poravnava sekvenc, evolucijski algoritem, križanje, mutacija, optimizacija

\section{UVOD}

Poravnava sekvenc je metoda, pri kateri je cilj najti podobnosti med naborom dveh (angl. pair-wise alignment) ali več (angl. multiple sequence alignment) sekvenc simbolov [8]. $\mathrm{V}$ bioinformatiki se sekvence DNK, RNK in proteinov poravnavajo $\mathrm{z}$ namenom iskanja skupnih značilnosti, ki bi nakazovale evolucijsko povezavo [8]. Težave pri poravnavah se pojavijo zaradi tega, ker se s procesom evolucije skozi čas v sekvencah pojavijo mutacije, kot so vnosi, brisanje in substitucija genetskih informacij, kar povzroči razlike med sekvencami [7].

Sekvence so predstavljene po vrsticah, v katerih poskušamo simbole preurediti na takšen način, da bo končni rezultat matrika, ki ima po stolpcih čim več enakih ali podobnih simbolov [8]. Po potrebi se v sekvence vnesejo tudi vrzeli (angl. gaps) z namenom pridobitve čim bolj optimalne poravnave [1]. V primeru sekvenc DNK so baze adenin, citozin, gvanin in timin $\mathrm{v}$ sekvenci predstavljene s simboli A, C, G in T. Primer poravnave treh manjših sekvenc DNK z vnosom vrzeli prikazuje slika 1 . Najbolj optimalna poravnava je bila dosežena z povečanjem maksimalne dolžine sekvenc in vstavljanjem vrzeli.

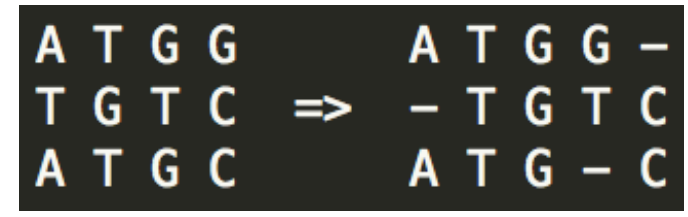

Slika 1: Primer poravnave sekvenc z vnosom vrzeli.

V literaturi zasledimo, da so se pri poravnavi dveh sekvenc izkazali za zelo uspešne algoritmi, ki uporabljajo metode dinamičnega programiranja. Že leta 1970 sta Needleman in Wunsch predlagala metodo za poravnavo dveh sekvenc [9]. Dinamično programiranje se ne uporablja za primerjavo večjega števila sekvenc zaradi računske zahtevnosti $O\left(n^{k}\right)$, kjer $k$ predstavlja število sekvenc [7]. Zaradi velike računske zahtevnosti se pri primerjavi večjega števila sekvenc uporabljajo metode, ki ne zagotavljajo najboljše poravnave [8]. Med takšne spadajo progresivne metode [5], ki so med drugimi implementirane tudi v Clustal Omega [12] in T-Coffee [10]. Drugi možen pristop so iterativne metode, ki poskušajo skozi iteracije izboljšati začetno rešitev tako, da maksimizirajo dano ocenitveno funkcijo [8]. Med iterativne pristope spada tudi naša implementacija z evolucijskim algoritmom [8].

V drugem poglavju opišemo implementiran algoritem za poravnavo sekvenc s pomočjo evolucijskega algoritma. V tretjem poglavju predstavimo program in eksperimente, kjer testiramo uspešnost algoritma na različnih sekvencah DNK. Zadnje poglavje je namenjeno razpravi.

\section{EVOLUCIJSKI ALGORITEM}

Evolucijski algoritmi so metode, ki poskušajo z oponašanjem naravnih procesov križanja, mutacije in selekcije izboljšati populacijo kandidatov. Primerni so za reševanje različnih kombinatoričnih problemov kot sta npr. optimizacija zvijanja proteinov [2] in poravnava sekvenc. $\mathrm{V}$ našem algoritmu so sekvence $\mathrm{v}$ kandidatih predstavljene $\mathrm{v}$ dvodimenzionalnem polju po vrsticah. $\mathrm{V}$ algoritmu je vsak kandidat $\mathrm{v}$ populaciji generiran naključno glede na vhodne sekvence in predstavlja potencialno rešitev. Implementacijo algoritma prikazuje slika 2 .

Kvaliteto kandidatov smo ocenili z metodo vsote parov (angl. sum of pairs) [11], pri kateri smo vsak stolpec ovrednotili po naslednji enačbi: 


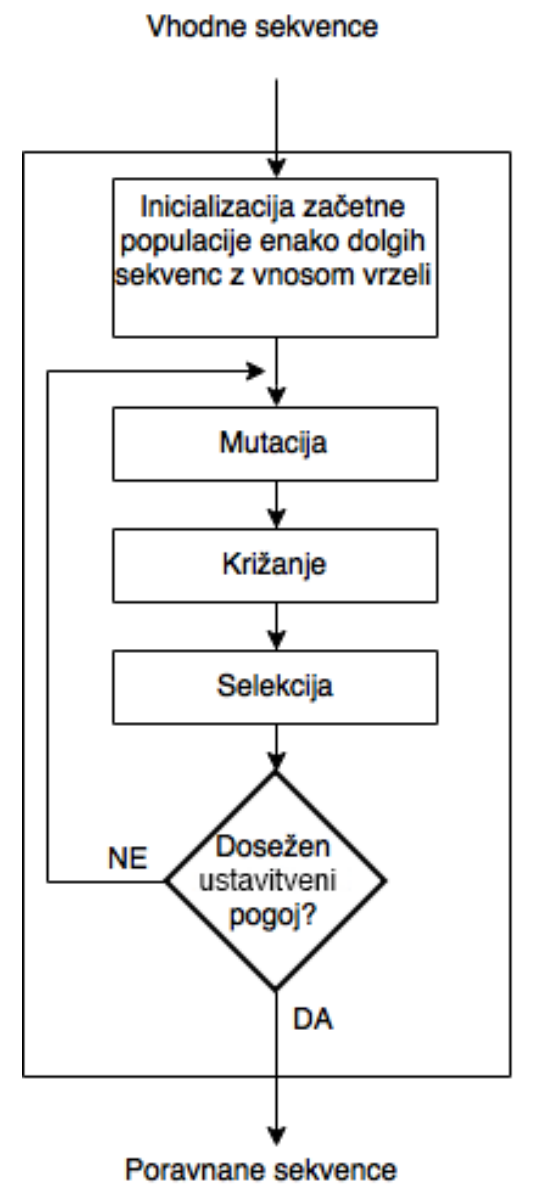

Slika 2: Potek evolucijskega algoritma.

$$
S P \_C(i)=\sum_{1 \leq p \leq q \leq k} \operatorname{eval}\left(S_{p, i}, S_{q, i}\right)
$$

- $i$ - oznaka stolpca

- $p, q$ - oznaki sekvenc

- $k$ - število vseh sekvenc

- $S$ - sekvenca

V vsakem stolpcu smo medsebojno primerjali simbole, kjer se je $\mathrm{h}$ končni oceni ocenitvene funkcije dodala vrednost po naslednjih kriterijih [7]:

- 2 v primeru dveh enakih simbolov,

- $-2 \mathrm{v}$ primeru dveh vrzeli in

- $-1 \mathrm{v}$ primeru vrzeli in simbola.

Primer uporabe metode sume parov na treh sekvencah prikazuje slika 3 , kjer je bil končni rezultat ocenitvene funkcije suma vseh vrednosti stolpcev.

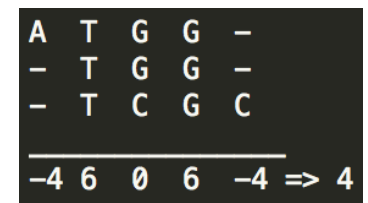

Slika 3: Primer izračuna sume parov na treh sekvencah.

Za uspešno poravnavo sekvenc je potrebno imeti sekvence enakih dolžin. Zaradi mutacij zelo pogosto to ni možno, kar smo rešili z vstavljanjem vrzeli. Dolžino sekvenc smo zato določili po enačbi:

$$
L=l_{\max } \times\left(1+r_{s p}\right)
$$

kjer $l_{\max }$ predstavlja najdaljšo sekvenco in $r_{s p}$ skalirni faktor, $\mathrm{s}$ katerim povečamo dolžino sekvenc [7]. $r_{s p}$ je pozitivno število za katerega je priporočena vrednost 0,2 [7]. Določiti primerno dolžino sekvenc je pomembno, ker se v primeru premajhne vrednosti lahko zgodi, da ne najdemo optimalne rešitve pri sekvencah s slabšo podobnostjo, in nasprotno, pri predolgih sekvencah prevelik iskalni prostor lahko pomeni, da bo iskanje optimalne rešitve lahko trajalo veliko dlje časa [7]. Vsako sekvenco naključno zapolnimo z vrzelmi tako, da bo imela dolžino $L$.

Lokacije vrzeli smo generirali podobno kot v [3], s tem da smo v vsaki sekvenci ustvarili permutacijo $L$ števil za vsako sekvenco. Iz vsake permutacije smo vzeli toliko števil, kot je originalna dolžina sekvence in jih uredili po naraščajočem vrstnem redu. Ta števila predstavljajo lokacije simbolov $\mathrm{v}$ sekvenci. Preostale indekse smo zapolnili z vrzelmi. Če imamo v kandidatu na primer DNK sekvenco: CTG, kjer je vrednost $L$ enaka 5 in generirano permutacijo: $3,2,5,1,4$; bo izgled končne sekvence: -CT-G.

Križanje smo povzeli po [6], kjer se je naključnega kandidata iz populacije z trenutnim lahko križalo horizontalno ali vertikalno. Tip križanja je bil izbran naključno, možnost obeh križanj je bila $50 \%$. Horizontalno križanje deluje tako, da smo za vsako vrstico v križancu naključno izbrali sekvenco iz enega od kandidatov (slika 5). Pri vertikalnem križanju smo naključno izbrali točko preseka, pri kateri dobi križanec vsebino vsake sekvence do točke preseka skopirano od prvega kandidata in od točke preseka naprej od drugega kandidata (slika 4). Pri vertikalnem križanju smo morali paziti, da se struktura bioloških sekvenc ohrani.

Mutacijski operator je bil implementiran tako, da smo naključno izbrali sekvenco $\mathrm{v}$ kandidatu in poiskali takšen simbol, ki je imel vsaj eno sosednjo vrzel. Za vsako sosednjo vrzel izbranega simbola smo zamenjali simbola $\mathrm{v}$ indeksih sekvence in preverili novo vrednost ocenitvene funkcije. Od vseh možnih zamenjav smo izbrali različico kandidata z največjo vrednostjo ocenitvene funkcije [3].

$\mathrm{V}$ procesu selekcije smo mutiranca zamenjali s trenutnim kandidatom v populaciji v primeru, če je bil bolje ovrednoten s strani ocenitvene funkcije.

\section{EKSPERIMENTI}




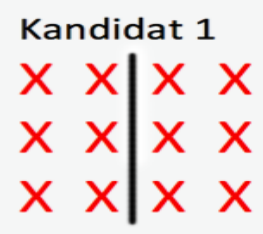

Kandidat 2

\begin{tabular}{ll|ll}
$X$ & $x$ & $X$ & $x$ \\
$X$ & $x$ & $X$ & $x$ \\
$X$ & $x$ & $x$ & $X$
\end{tabular}

Slika 4: Vertikalno križanje.

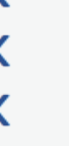

\section{Križanec}

$x \times \times \times$

$x \times x \times$

$x \times \times \times$

\section{trižanje.}

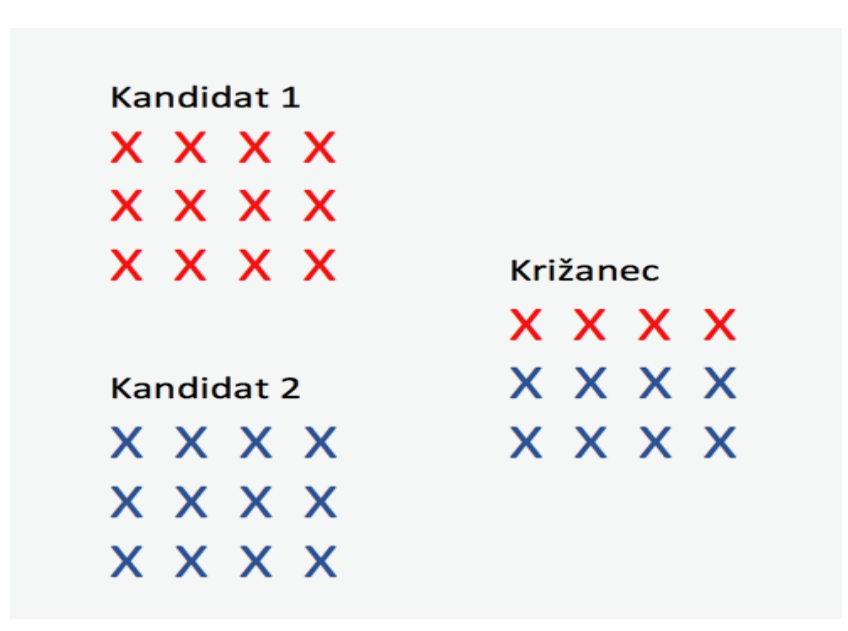

Slika 5: Horizontalno križanje.

Zaradi hitrosti smo algoritem implementirali v jeziku $\mathrm{C}++$. Eksperimente smo izvajali na osebnem računalniku z 16GB spomina, $2.2 \mathrm{GHz}$ Intel Core i7 procesorjem in MacOS operacijskim sistemom.

Učinkovitost algoritma smo primerjali z uveljavljenim programskim orodjem Clustal Omega, ki spada v družino programov Clustal (http://www.ebi.ac.uk/Tools/msa/clustalo/) Uspešnost poravnav obeh algoritmov smo ocenili s številom polno ujemajočih se stolpcev v poravnavi. Uporabili smo podoben nabor podatkov, kot je bil uporabljen v [4] (tabela 2). Sekvence omenjene v [4] smo prenesli iz spletne strani evropskega inštituta za bioinformatiko (http://www.ebi.ac.uk).

$\mathrm{V}$ implementiranem programu smo sekvence podali v tekstovnem formatu FASTA in nastavili parametre, kot jih prikazuje tabela 1. Algoritem smo ustavili, po 100000 klicih ocenitvene funkcije.

Kot je vidno iz tabele 3 , nam je na skupini sekvenc D1 in D2 uspelo polno poravnati 43 in 111 stolpcev. Programsko orodje Clustal Omega pa se je na istih sekvencah izkazalo za boljše z 854 polno poravnanimi stolpci v skupini sekvenc
Tabela 1: Nastavitve algoritma.

\begin{tabular}{|l|l|}
\hline Parameter & Vrednost \\
\hline Velikost populacije & 60 \\
Dovoljeno št. ovrednotenj & 100000 \\
Prostorsko razmerje & 0,2 \\
Horizontalno križanje & 0,5 \\
Vertikalno križanje & 0,5 \\
\hline
\end{tabular}

Tabela 2: Nabor podatkov [4].

\begin{tabular}{|c|c|c|c|}
\hline Ime & $\begin{array}{l}\text { Št. se- } \\
\text { kvenc }\end{array}$ & $\begin{array}{l}\text { Povprečna dolžina } \\
\text { (Najkrajša sekv., } \\
\text { Najdaljša sekv.) }\end{array}$ & $\begin{array}{l}\text { Identifikatorji } \\
\text { sekvenc }\end{array}$ \\
\hline D1 & 5 & $1092(1006,1142)$ & $\begin{array}{ll}\text { M60059, } & \text { M60060, } \\
\text { M60061, } & \text { M60062, } \\
\text { M60063 } & \end{array}$ \\
\hline$\overline{\mathrm{D} 2}$ & 6 & $212(211,212)$ & $\begin{array}{ll}\text {Z75841, } & \text { Z75850, } \\
\text { Z75854, } & \text { Z75852, } \\
\text { Z75858, } & \text { Z75851 }\end{array}$ \\
\hline
\end{tabular}

D1 in 206 v skupini sekvenc D2.

\begin{tabular}{|l|l|l|}
\multicolumn{2}{c}{ Tabela 3: Rezultati } \\
\hline Ime & $\begin{array}{l}\text { St. ujemajočih } \\
\text { stolpcev z EA }\end{array}$ & $\begin{array}{l}\text { St. ujemajočih } \\
\text { stolpcev z Clustal } \\
\text { Omega }\end{array}$ \\
\hline D1 & 43 & 854 \\
D2 & 111 & 206 \\
\hline
\end{tabular}

\section{ZAKLJUČEK}

$\mathrm{V}$ članku smo predstavili metodo poravnave sekvenc s pomočjo evolucijskega algoritma. Z našo implementacijo smo uspeli doseči poravnavo sekvenc DNK. Algoritem bi lahko izboljšali v procesu mutacije, kjer bi z več različnimi tipi mutacij lahko dosegli večjo raznolikost populacije. Potrebno bi bilo narediti tudi analizo vrednosti krmilnih parametrov. Npr. z večjo populacijo in daljšim evolucijskim procesom bi verjetno dobili boljše rezultate. Implementacija bolj kompleksne ocenitvene funkcije in generacija začetne populacije, ki ni naključno generirana, predstavljata tudi dve izboljšavi za pridobitev boljše končne poravnave. Razvoj algoritma se bo nadaljeval $\mathrm{v}$ magistrskem delu, kjer bomo poleg poravnave sekvenc DNK implementirali še zmožnost poravnave proteinov s pomočjo različnih ocenitvenih matrik. Algoritem bomo bolj podrobno primerjali z drugimi sorodnimi rešitvami na večjem naboru podatkov.

\section{Zahvala}

Janez Brest in Borko Bošković priznavata financiranje prispevka s strani Javne agencije za raziskovalno dejavnost Republike Slovenije, raziskovalni program P2-0041 - Računalniški sistemi, metodologije in inteligentne storitve.

\section{LITERATURA}

[1] PORAVNAVANJE ZAPOREDIJ. http://web.bf .uni-lj.si/bi/biokemija/bioinfo/ 2007/Material/Poravn1.htm, 2007. [Online; accessed 29-August-2017].

[2] B. Bošković and J. Brest. Genetic Algorithm with Advanced Mechanisms Applied to the Protein 
Structure Prediction in a Hydrophobic-Polar Model and Cubic Lattice. Applied Soft Computing, 45:61-70, 2016.

[3] K. Chellapilla and G. B. Fogel. Multiple sequence alignment using evolutionary programming. In Proceedings of the 1999 Congress on Evolutionary Computation-CEC99 (Cat. No. 99TH8406), volume 1, page 452 Vol. 1, 1999.

[4] S. Chen, C. Lin, et al. Multiple dna sequence alignment based on genetic simulated annealing techniques. International journal of information and management sciences, 18(2):97, 2007.

[5] D.-F. Feng and R. F. Doolittle. Progressive sequence alignment as a prerequisitetto correct phylogenetic trees. Journal of Molecular Evolution, 25(4):351-360, Aug 1987.

[6] C. Gondro and B. Kinghorn. A simple genetic algorithm for multiple sequence alignment. Genetics and Molecular Research, 6(4):964-982, 2007.

[7] J.-T. Horng, L.-C. Wu, C.-M. Lin, and B.-H. Yang. A genetic algorithm for multiple sequence alignment. Soft Computing, 9(6):407-420, Jun 2005.

[8] D. W. Mount. Bioinformatics: Sequence and Genome Analysis 2nd edition. Cold Spring Harbor Laboratory Press, 1986.

[9] S. Needleman and C. Wunsch. A general method applicable to the search for similarities in the amino acid sequence of two proteins. Journal of Molecular Biology, 48(3):443-453, 31970.

[10] C. Notredame, D. G. Higgins, and J. Heringa. T-coffee: A novel method for fast and accurate multiple sequence alignment. $J \mathrm{Mol} \mathrm{Biol,}$ 302(1):205-17, Sep 8 2000. Journal ArticleResearch Support, Non-U.S. Gov't.

[11] J. C. Setubal and J. Meidanis. Introduction to Computational Molecular Biology. Computer Science Series. PWS Pub., 1997.

[12] F. Sievers, A. Wilm, D. Dineen, T. J. Gibson, K. Karplus, W. Li, R. Lopez, H. McWilliam, M. Remmert, J. Söding, J. D. Thompson, and D. G. Higgins. Fast, scalable generation of high-quality protein multiple sequence alignments using clustal omega. Molecular Systems Biology, 7(1), 2011. 